\title{
Induction of infertility by the Chlamydia trachomatis mouse pneumonitis biovar in strains of mice that differ in their response to the $60 \mathrm{kDa}$ heat shock protein
}

\author{
A. Khamesipour, S. Pal, E. M. Peterson and L. M. de la Maza ${ }^{*}$ \\ Department of Pathology, Medical Sciences I, University of California, Irvine, CA 92717-4800,
}

USA

\begin{abstract}
To determine the role that the host response to the chlamydial $60 \mathrm{kDa}$ heat shock protein (hsp) plays in the pathogenesis of infertility, $\mathrm{C} 3 \mathrm{H} / \mathrm{HeN}\left(\mathrm{H}-2^{\mathrm{k}}\right)$ and $\mathrm{C} 57 \mathrm{BL} / 6\left(\mathrm{H}-2^{\mathrm{b}}\right)$ mice were inoculated in the left ovarian bursa with $1 \times 10^{5}$ inclusion forming units of the Chlamydia trachomatis mouse pneumonitis $(\mathrm{MoPn})$ biovar, and in the right ovarian bursa with mock-infected HeLa-229 cell extracts. Control mice were inoculated with mockinfected HeLa-229 cell extracts. These two strains of mice were chosen because the $\mathrm{C} 3 \mathrm{H}$ mice mount a strong immune response to the $60 \mathrm{kDa}$ hsp, whereas the $\mathrm{C} 57 \mathrm{BL} / 6$ mice respond only weakly. Vaginal cultures obtained after inoculation were positive for 4 weeks in both strains of mice. Histological sections showed a marked acute inflammatory infiltrate that permeated all the layers of the oviduct and lasted for approximately 2 weeks in both strains. By the third week, mononuclear inflammatory cells were also observed and from 4 weeks after inoculation, hydrosalpinx formation was observed, particularly in the $\mathrm{C} 3 \mathrm{H}$ mice. An inclusion immunofluorescence assay detected antibodies specific for chlamydia in the serum and the vaginal washes of the $\mathrm{C} 3 \mathrm{H}$ and $\mathrm{C} 57 \mathrm{BL} / 6$ mice. Western blot analysis of the serum samples showed an immune response to lipopolysaccharide, and the 30, 40 (major outer membrane protein) and $60 \mathrm{kDa}$ cysteine-rich protein in both strains of mice. In addition, in the $\mathrm{C} 3 \mathrm{H}$ mice a strong immune reaction was mounted against a $50 \mathrm{kDa}$ component and the $60 \mathrm{kDa}$ hsp. Six weeks after inoculation, the female mice were mated with male mice of proven fertility and the outcome of the pregnancies evaluated. Of the mock-infected $\mathrm{C} 3 \mathrm{H}$ and $\mathrm{C} 57 \mathrm{BL} / 6$ mice, $73 \%$ and $82 \%$ were bilaterally pregnant, respectively. In contrast, only $8 \%$ of the $\mathrm{C} 3 \mathrm{H}$ and $25 \%$ of the $\mathrm{C} 57 \mathrm{BL} / 6$ mice inoculated with the $C$. trachomatis MoPn were bilaterally pregnant $(P<0.05)$. Furthermore, there were significantly fewer embryos in the right and left uterine horns of $\mathrm{C} 3 \mathrm{H}$ mice in the animals inoculated with $C$. trachomatis than in controls, whereas in the $\mathrm{C} 57 \mathrm{BL} / 6$ mice there were fewer embryos only in the left uterine horn. In conclusion, inoculation of the $C$. trachomatis $\mathrm{MoPn}$ into the ovarian bursa results in infertility in both the $\mathrm{C} 3 \mathrm{H}$ and $\mathrm{C} 57 \mathrm{BL} / 6$ mice. However, the effect was greater in the $\mathrm{C} 3 \mathrm{H}$ mice than in the $\mathrm{C} 57 \mathrm{BL} / 6$ mice.
\end{abstract}

\section{Introduction}

Chlamydia trachomatis is a human pathogen that has been found to cause ocular and genital infections in many countries throughout the world (Schachter, 1983; Mardh, 1985; Westrom, 1989). In females, after a symptomatic or an asymptomatic genital tract infection, the disease resolves spontaneously in most instances, but in some patients long-term sequelae such as chronic pelvic pain, infertility and tubal pregnancy may occur (Westrom, 1975, 1980; Gump et al., 1983; Westrom and Mardh, 1983). There is great interest in developing measures to prevent the sequelae of this infection

${ }^{*}$ Correspondence.

Received 20 September 1993.
(Grayston and Wang, 1978; Ward, 1992). Although several antimicrobial agents are effective in eradicating a chlamydial infection, the problem of asymptomatic patients can be successfully addressed only by a vaccine. Thus, several animal models have been used in an attempt to understand the immunopathogenesis of chlamydial infections and to evaluate the efficacy of preventive measures (Barron et al., 1981; Patton et al, 1983; Swenson et al., 1983; Swenson and Schachter, 1984; Tuffrey et al., 1986).

Swenson et al. (1983) established a salpingitis model by infecting Swiss Webster white mice with the mouse pneumonitis (MoPn) biovar of $C$. trachomatis. After an intrabursal or intrauterine inoculation with $C$. trachomatis $\mathrm{MoPn}$, the mice developed acute salpingitis and a significant number of animals became infertile (Swenson and Schachter, 1984). One of the 
advantages of this model is that the $C$. trachomatis MoPn biovar is of murine origin and can produce a genital infection in mice effectively (Nigg, 1942; Nigg and Eaton, 1944). Furthermore, recent analysis of the DNA sequence of the C. trachomatis MoPn major outer membrane protein has shown that it has the same overall molecular structure as the major outer membrane protein of the human serovars, including the presence of four variable domains, and is phylogenetically closely related to the human isolates (Fielder et al., 1991; Fitch et al., 1993). Tuffrey et al. (1986) also established a mouse model of salpingitis by inoculating the upper genital tract of outbred and inbred strains of mice with the human C. trachomatis serovars. For this model, mice were pretreated with progesterone to prevent oestrus in order to produce salpingitis and infertility efficiently.

The pathogenesis of the damage leading to trachoma or infertility secondary to a chlamydial infection is poorly understood. In some experimental models of trachoma it appears that the chlamydial $60 \mathrm{kDa}$ heat shock protein (hsp) may play a role in the process that leads to the scarring of the conjunctiva (Watkins et al., 1986; Taylor et al., 1987, 1990; Morrison et al., $1989 a, b)$. In addition, patients with tubal infertility and ectopic pregnancy have a high concentration of antibodies to the $60 \mathrm{kDa}$ hsp (Wagar et al., 1990; Coles et al., 1991; Brunham et al., 1992). On the basis of these observations, Morrison et al. (1990) postulated that owing to the similarities in amino acid composition between the bacterial and the human $60 \mathrm{kDa} h \mathrm{hp}$ an autoimmune reaction may occur that results in scarring of the affected tissues. Zhong and Brunham (1992) showed that the ability of inbred strains of mice to develop an immune response to the $60 \mathrm{kDa}$ hsp may, at least in part, be modulated by the $\mathrm{H}-2$ loci. Among the several inbred strains of mice tested, they found that the $\mathrm{C} 3 \mathrm{H}\left(\mathrm{H}-2^{k}\right)$ strain mounted a high antibody response to the $60 \mathrm{kDa}$ hsp, whereas the C57BL/6 $\left(\mathrm{H}-2^{\mathrm{b}}\right)$ mice developed low antibody titres. We therefore investigated the ability of the $C$. trachomatis $\mathrm{MoPn}$ serovar to produce salpingitis in these two inbred strains of mice to determine whether reactivity to the $60 \mathrm{kDa}$ hsp correlated with tubal infertility.

\section{Materials and Methods}

\section{Organisms}

The C. trachomatis MoPn serovar (strain Nigg II) was purchased from the American Type Culture Collection (Rockville, MD) and was grown in HeLa-229 cells. Stocks were cultured for $40 \mathrm{~h}$, and the elementary bodies purified through Renografin gradients, and stored at $-70^{\circ} \mathrm{C}$ in sucrose phosphate glutamate buffer (SPG) until used (Caldwell et al., 1981).

\section{Mice}

Six-eight-week-old C57BL/6N $\left(\mathrm{H}-2^{b}\right)$ and $\mathrm{C} 3 \mathrm{H} / \mathrm{HeN}\left(\mathrm{H}-2^{k}\right)$ female and male mice of proven fertility were obtained from Simonsen Laboratories (Gilroy, CA) and maintained in a $12 \mathrm{~h}$ light: $12 \mathrm{~h}$ dark cycle.

For inoculation, 20 female mice from each strain were anaesthetized with Metofane by inhalation in a closed glass jar for 2-3 min (Pitman-Moore, Mundelein, IL); their abdominal cavities were surgically opened and $1 \times 10^{5}$ inclusion forming units (IFUs) of C. trachomatis MoPn, in $20 \mu \mathrm{l}$ of SPG, placed into the left ovarian bursa using a Hamilton syringe and a 30 gauge needle ( $\mathrm{Pal}$ et al., 1993). In the right ovarian bursa the inoculum consisted of HeLa-229 cell extracts obtained in a similar manner to the $C$. trachomatis IFUs but using mockinfected HeLa-229 cells. Groups of 20 mice of each strain were treated in an identical manner but the inoculum consisted of mock-infected HeLa-229 cells in both the right and left ovarian bursa.

\section{Culture for Chlamydia trachomatis $\mathrm{MoPn}$}

Vaginal swabs were collected from each mouse, placed in $0.25 \mathrm{ml}$ of SPG, vortexed and the inoculum immediately transferred to a 24 well plate (Corning Glass Works, New York, NY) with McCoy cells. The plate was centrifuged for $1 \mathrm{~h}$ at $1000 \mathrm{~g}$ at room temperature. After centrifugation Eagle's minimum essential medium (EMEM) containing 5\% fetal bovine serum (FBS) and cycloheximide $\left(1 \mu \mathrm{g} \mathrm{ml}^{-1}\right)$ was added and the monolayers incubated at $37^{\circ} \mathrm{C}$ for $48 \mathrm{~h}$ in a $\mathrm{CO}_{2}$ incubator. The monolayers were fixed with methanol and stained with a polyclonal rabbit anti-C. trachomatis $\mathrm{MoPn}$ sera raised in our laboratory. A horseradish peroxidase (HRP) conjugated goat anti-rabbit antibody (Cappel Research Products, Durham, NC) was used to stain the inclusions that were visualized with a 4-chloro-I-naphthol solution (Cappel) (Peterson et al., 1988). The number of inclusions in each well was counted under a light microscope.

\section{Histopathology}

Tissue sections from the upper genital tract of two mice, killed at different times after inoculation, were fixed in buffered formalin and processed for light microscopy using routine procedures (Pal et al., 1993).

\section{Measurement of the antibody response by inclusion immunofluorescence assay}

Blood samples were collected by retro-orbital puncture, or by cardiac puncture at the time the mice were killed by exsanguination following anaesthesia. Serum was separated and stored individually or pooled for each group of mice at $-70^{\circ} \mathrm{C}$ until tested. Genital secretions were collected by washing the vaginal cavity twice with $20 \mu \mathrm{l}$ PBS, pooled for each group of animals, and stored at $-70^{\circ} \mathrm{C}$ until tested. Antibody titres were measured by the inclusion immunofluorescence assay using MCoy cell monolayers infected with the C. trachomatis MoPn biovar as described by Peterson et al. (1989).

\section{Immunoblots}

The western blots were performed as described by Schagger and von Jagow (1987) and $\mathrm{Pal}$ et al. (1993). Briefly, C. trachomatis EBs $(250 \mu \mathrm{g})$ and the affinity purified $60 \mathrm{kDa}$ hsp $(100 \mu \mathrm{g})$ from the $C$. trachomatis serovar A [kindly supplied by 
R. Morrison (Rocky Mountain Laboratory, Hamilton, MT)] were loaded on a $7.5 \mathrm{~cm}$ wide mini slab gel. The antigens were subjected to electrophoresis under standard conditions and subsequently transferred to the nitrocellulose membranes. Undiluted vaginal washes or serum samples diluted 1:100 with PBS containing $0.05 \%$ Tween 20 were incubated with the nitrocellulose membrane strips for $2 \mathrm{~h}$ at room temperature. Monoclonal antibodies against the $C$. trachomatis serovar A $60 \mathrm{kDa}$ hsp (a generous gift from R. Morrison), and the 40 (major outer membrane protein) and $60 \mathrm{kDa}$ cysteine-rich proteins (produced in our laboratory) were used as positive controls. After washing, the strips were incubated with HRP. conjugated goat anti-mouse IgM, IgG and IgA (Cappel) and visualized with a 4-chloro-I-naphthol solution.

\section{Assessment of fertility}

At 6 weeks after intrabursal inoculation, the $C$. trachomatis infected and the mock-infected mice were mated with male mice of proven fertility (3-4 females per male). The weight of the female mice was determined at 18 days after mating and female mice found to be gaining weight were killed, and the number of embryos in the left and the right uterine horn were recorded. Female mice that did not gain weight were separated from the males for 10 days and then mated again and monitored as described during the first mating. After the second mating, all animals that were not gaining weight were killed at 30 days from the first day of the second mating and checked for the presence of embryos.

\section{Statistical analyses}

Statistical analyses were performed using the two-tailed unpaired Student's $t$ test.

\section{Results}

\section{Vaginal cultures}

Chlamydia trachomatis MoPn was recovered, at least once, from the vagina of all except one $\mathrm{C} 3 \mathrm{H}$ mouse and one $\mathrm{C} 57 \mathrm{BL} / 6$ mouse from 1 week after inoculation. By week $2,92 \%$ of the $\mathrm{C} 3 \mathrm{H}$ mice and $50 \%$ of the $\mathrm{C} 57 \mathrm{BL} / 6$ mice had positive vaginal cultures (Fig. 1a). The percentage of mice with positive cultures was higher for the $\mathrm{C} 3 \mathrm{H}$ than for the $\mathrm{C} 57 \mathrm{BL} / 6$ mice for the entire duration of the experiment. From week 3 after inoculation, the number of mice with positive cultures declined and by the end of week 4 , the cultures were negative. Cultures for C. trachomatis were negative for the control animals throughout the experiment. Overall, the number of IFUs recovered from the vaginal cultures was higher for the $\mathrm{C} 3 \mathrm{H}$ mice than for the C57BL/6 mice (Fig. Ib). The peak number of $C$. trachomatis IFUs recovered from the vagina was detected at 9 days after inoculation in both strains of mice and subsequently declined fairly rapidly. At 9 days after inoculation, the average number of IFUs in the $\mathrm{C} 3 \mathrm{H}$ mice was 9061 (range 0-92 928) and for the $\mathrm{C} 57$ it was 12538 (range 0-135 168).

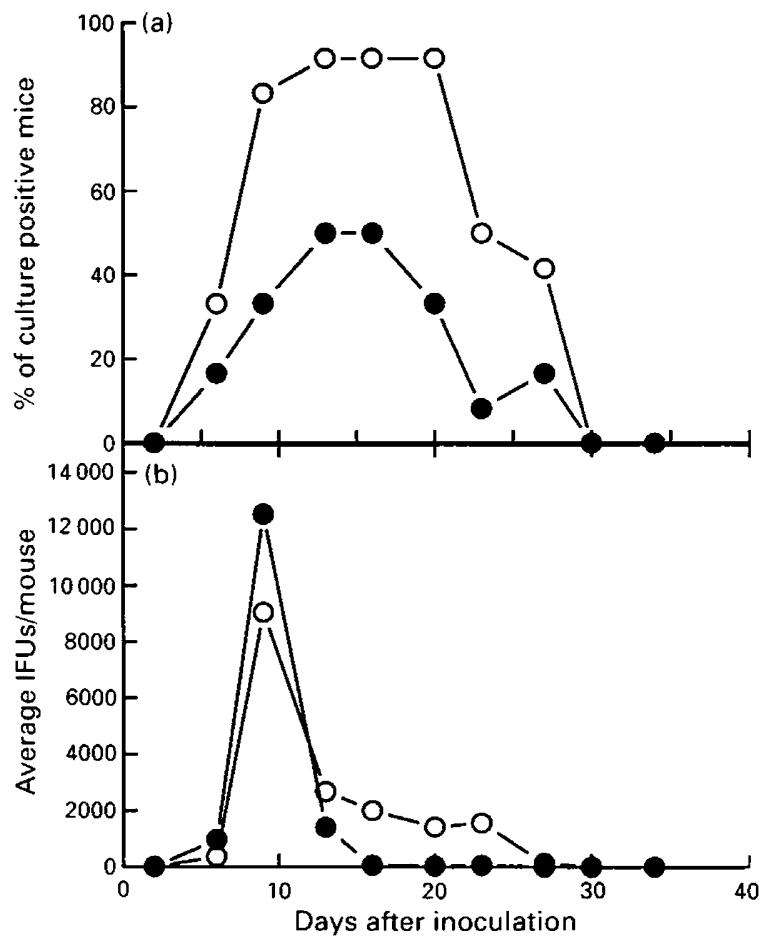

Fig. 1. (a) Percentage of $(\mathrm{O}) \mathrm{C} 3 \mathrm{H}$ and $(O) \mathrm{C} 57 \mathrm{BL} / 6$ mice with a positive vaginal culture for Chlamydia trachomatis mouse pneumonitis $(\mathrm{MoPn})$ biovar. (b) Average number of $\mathrm{C}$. trachomatis MoPn inclusion forming units (IFUs) detected in the vaginal secretions of $(O) \mathrm{C} 3 \mathrm{H}$ and (O) C57BL/6 mice.

\section{Histopathology}

At intervals of approximately $I$ week two animals from each strain of mice were killed to assess the pathological changes. Up to 21 days after inoculation, gross examination of the mice inoculated with $C$. trachomatis MoPn in the left uterine horn revealed a significant reddening of the serosal surface with vascular engorgement. Of the six $\mathrm{C} 3 \mathrm{H}$ mice examined from day 28 to day 42 after inoculation, hydrosalpinx formation was noted in three right and five left uterine horns. By contrast, only one uterine horn was found to be dilated in the C57BL/6 mice among the six animals killed during that period. Observation under microscope of the oviducts at 2 weeks after inoculation showed a marked acute inflammatory infiltrate consisting mainly of polymorphonuclear cells permeating all the layers of the oviduct accompanied by oedema with loss of the mucosal folds that in certain instances resulted in complete obliteration of the oviductal lumen (Fig. 2a, b). Both the right and left oviducts were affected in both strains of mice, although overall, the inflammatory infiltrate was more severe in the $\mathrm{C} 3 \mathrm{H}$ mice. By week 3 after inoculation, the inflammatory infiltrate was composed of a mixture of polymorphonuclear and mononuclear cells including plasma cells. The fimbria were oedematous and there was a marked loss of the normal architecture of the interior of the oviduct (Fig. 2c). By week 5 after inoculation, the oviducts of most of the $\mathrm{C} 3 \mathrm{H}$ mice were markedly dilated with a complete loss of the fimbria and flattening or loss of the mucosal layer (Fig. 2d), while in the C57BL/6 mice the overall 

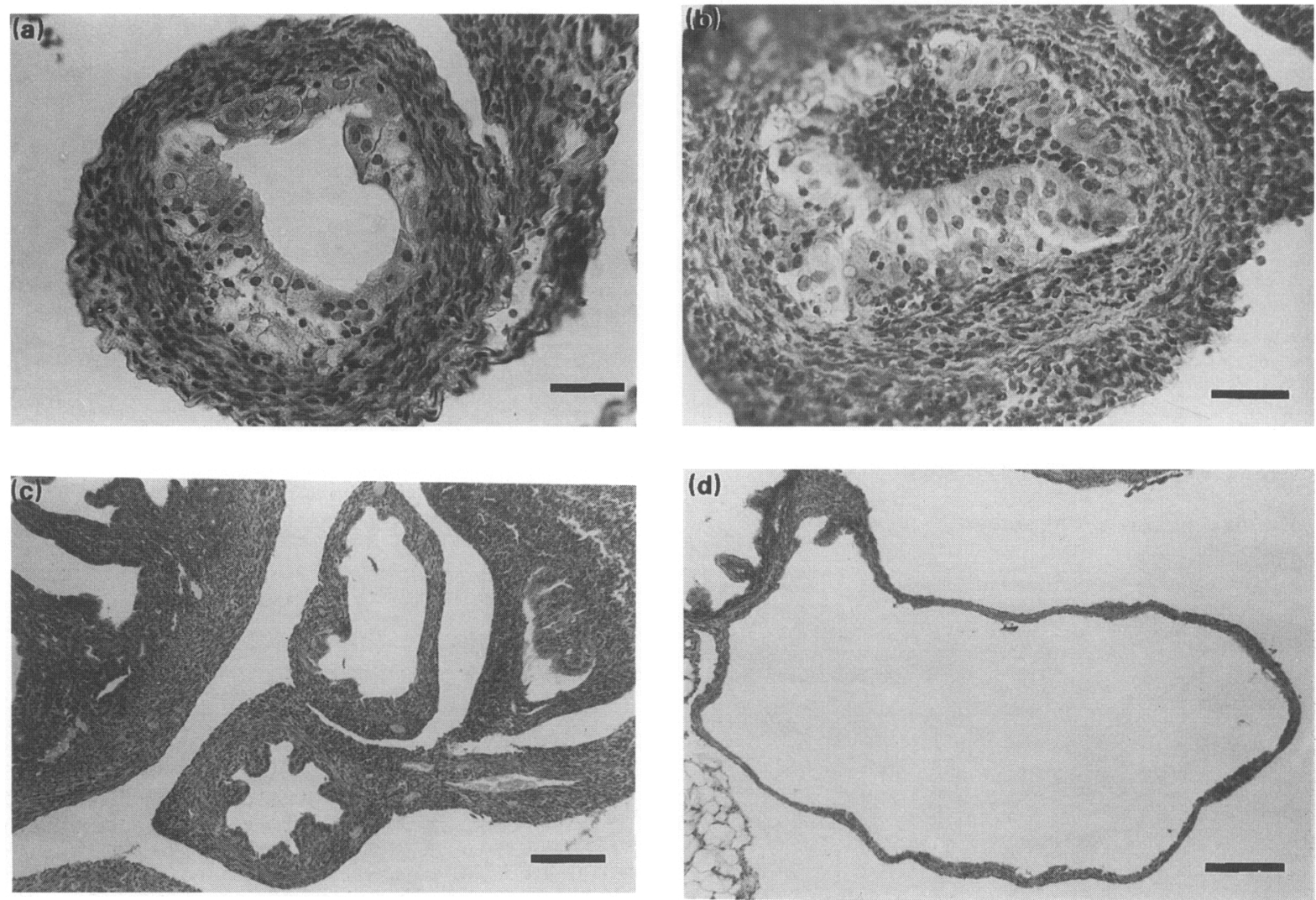

Fig. 2. (a) and (b) Sections of the right and left oviduct respectively, from C57BL/6 mice killed 2 weeks after intrabursal inoculation with Chlamydia trachomatis mouse pneumonitis biovar. Note the severe acute inflammatory infiltrate permeating all the layers of the oviduct and completely filling the lumen on the right side (Bars represent $31 \mu \mathrm{m}$ ). (c) Section of the left oviduct from a $\mathrm{C} 3 \mathrm{H}$ mouse 3 weeks after intrabursal inoculation with $C$. trachomatis. There is a mixed acute and chronic inflammatory infiltrate on the wall of the oviduct with a significant distortion of the overall architecture of the mucosal folds (Bar represents $100 \mu \mathrm{m}$ ). (d) Hydrosalpinx in a $\mathrm{C} 3 \mathrm{H}$ mouse infected with $\mathrm{C}$. trachomatis. This section corresponds to an animal killed 5 weeks after inoculation (Bar represents $100 \mu \mathrm{m}$ ).

structure of the oviduct was mostly well preserved. In the mock-inoculated control mice only a mild reddening of the serosal surface of the left uterine horn was noted during the first 2 weeks after inoculation and this was accompanied by a very mild acute inflammatory infiltrate. Subsequently no other changes were observed in the $\mathrm{C} 3 \mathrm{H}$ and $\mathrm{C} 57 \mathrm{BL} / 6$ control groups.

\section{Antibody response}

IgG chlamydial antibodies were detected, from 3 weeks after inoculation, in the mice inoculated with C. trachomatis MoPn, including the two mice that had negative vaginal cultures, when individual serum samples were tested. IgM chlamydial antibodies were first detected in pooled serum by IFA in the C57BL/6 mice at week 1 after inoculation; and peak values were reached at week 3 with a titre of 160 and values subsequently declined (Fig. 3a). The serum IgM antibodies in the $\mathrm{C} 3 \mathrm{H}$ mice followed a similar pattern, although they were first detected a week later and reached a peak titre value of 40 . IgG specific chlamydial antibodies in the $\mathrm{C} 57 \mathrm{BL} / 6$ and $\mathrm{C} 3 \mathrm{H}$ mice were detected at 1 and 2 weeks after inoculation, respectively, and increased to a titre of 640 by the end of week 5. $\operatorname{Ig} A$ was first detected at week 2 after inoculation in the two strains of mice and rose in parallel in the two groups for the duration of the experiment. Peak titres of 80 and 40 were observed in $\mathrm{C} 57 \mathrm{BL} / 6$ and $\mathrm{C} 3 \mathrm{H}$ mice at week 6 after inoculation, respectively.

IgG antibodies were first detected in the vaginal secretions in the $\mathrm{C} 3 \mathrm{H}$ mice by week 3 and in the C57BL/6 by week 4 (Fig. 4). In both strains of mice a peak titre of 32 was obtained by the end of the experiment. Vaginal $\operatorname{Ig} \mathrm{A}$ antibodies were detected first at week 4 after inoculation and rose to a titre of 4 by week 6 .

\section{Western blots}

At day 7 after inoculation of the C57BL/6 mice, the only bands detected corresponded to the lipopolysaccharide LPS and the $60 \mathrm{kDa}$ region (Fig. 5a). The major outer membrane protein and the 30 and $75 \mathrm{kDa}$ proteins were detected at day 12 after inoculation and this pattern remained the same for the 6 weeks of observation. No bands were detected in the $\mathrm{C} 3 \mathrm{H}$ mice until day 18 after inoculation. At that time, bands corresponding to the LPS, 30, 40 (major outer membrane protein) 50 and $60 \mathrm{kDa}$ region were detected. 


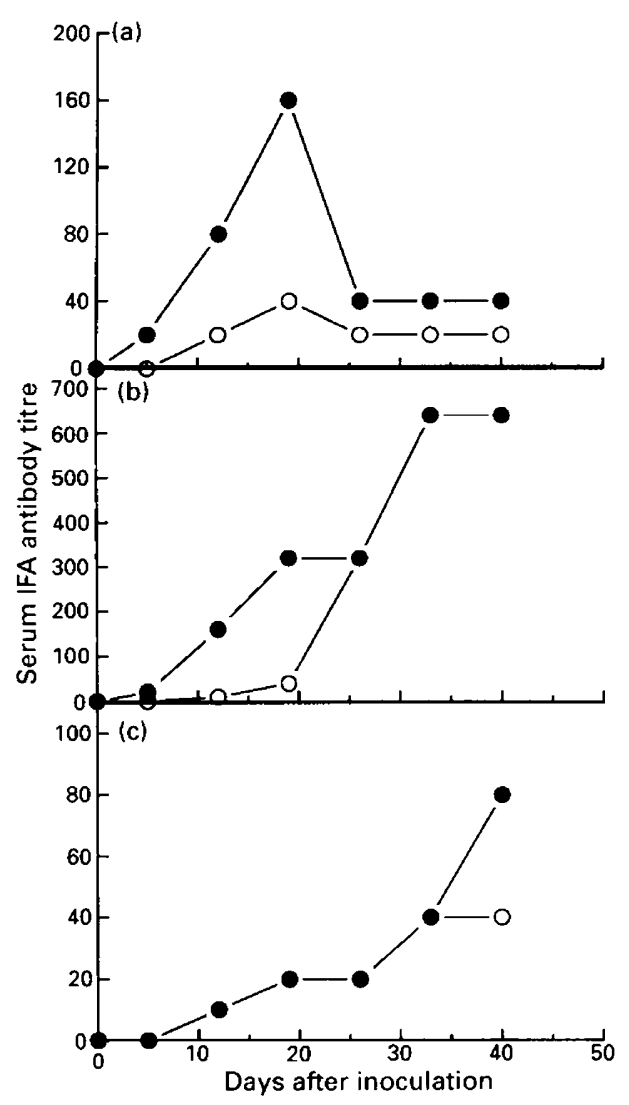

Fig. 3. (a) IgM-, (b) IgG- and (c) IgA-specific chlamydial immunofluorescence assay (IFA) titres in pooled sera from $(\mathrm{O}) \mathrm{C} 3 \mathrm{H}$ and $(0)$ C57BL/6 mice inoculated with Chlamydia trachomatis.

To determine the reactivity to the $60 \mathrm{kDa} h s p$, a recombinant $C$. trachomatis serovar A $60 \mathrm{kDa}$ hsp was probed with serum samples. A positive band at $60 \mathrm{kDa}$ was detected at day 42 after inoculation in the $\mathrm{C} 3 \mathrm{H}$ mice, while in the $\mathrm{C} 57 \mathrm{BL} / 6$ mice no band was observed (Fig. $5 b$ ).

Vaginal secretions were also analysed by western blot. A similar reactivity pattern to that observed in serum was measured in the vaginal secretions, although overall, the bands were weaker and there was a delay of several weeks in their appearance (Fig. $5 \mathrm{c}$ ). However, in the $\mathrm{C} 3 \mathrm{H}$ mice the strongest reactivity was to the major outer membrane protein and LPS, while in the C57BL/6 mice, the $60 \mathrm{kDa}$ and LPS were the most prominent bands.

\section{Fertility studies}

Of the $\mathrm{C} 3 \mathrm{H}$ mock-infected mice $73 \%$ (eight of 11 ) became bilaterally pregnant, one was unilaterally pregnant in the left uterine horn and two were unilaterally pregnant in the right uterine horn (Table 1). Of the $C$. trachomatis infected animals, only one of the 12 mice $(8 \% ; P<0.05)$ became bilaterally pregnant, one was unilaterally pregnant in the left uterine horn and four were unilaterally pregnant in the right uterine horn. The pregnant mock-infected mice had an average of 5.1 and 3.5 embryos in the right and left uterine horns, respectively.

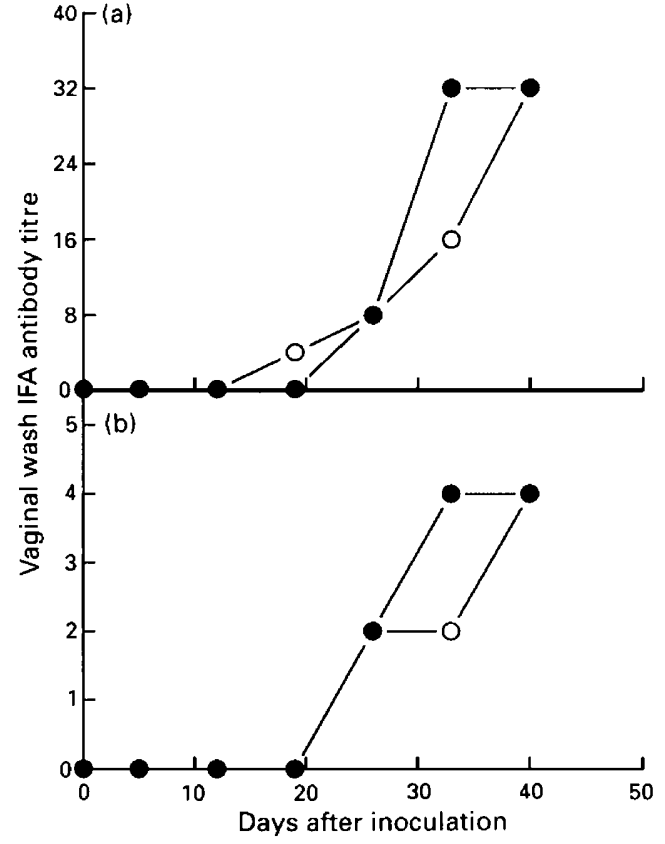

Fig. 4. (a) $\operatorname{IgG}$ and (b) $\lg A$-specific chlamydial immunofluorescence assay (IFA) titres from the vaginal pools of $(\mathrm{O}) \mathrm{C} 3 \mathrm{H}$ and $(\bullet) \mathrm{C} 57 \mathrm{BL} / 6$ mice injected with Chlamydia trachomatis mouse pneumonitis biovar.

In contrast $C$. trachomatis infected mice had on average $2.0(P=0.0126)$ and $0.7(P=0.0008)$ embryos per mouse in the right and left uterine horns, respectively.

In the mock-infected control C57BL/6 mice, $82 \%$ (nine of 11) of the animals became bilaterally pregnant and one was unilaterally pregnant in the right uterine horn. Of the C. trachomatis inoculated group only three of $12(25 \%$; $p<0.05)$ were bilaterally pregnant and six were unilaterally pregnant on the right side. The mock-infected mice had on average 3.8 embryos in both the right and left uterine horns, while the average number of embryos per mouse in the right and left uterine horns was $3.6(P=0.845)$ and $0.25(P=0.0001)$, respectively, in the mice infected with C. trachomatis.

\section{Discussion}

The results presented here show that inoculation of the C. trachomatis MoPn biovar into the ovarian bursa of two inbred strains of mice, $\mathrm{C} 3 \mathrm{H} / \mathrm{HeN}\left(\mathrm{H}-2^{\mathrm{k}}\right)$ and $\mathrm{C} 57 \mathrm{BL} / 6\left(\mathrm{H}-2^{\mathrm{b}}\right)$, produces an acute salpingitis that subsequently results in infertility. This occurs in spite of the fact that $\mathrm{C} 3 \mathrm{H}$ and $\mathrm{C} 57 \mathrm{BL} / 6$ mice have a high and a low antibody response to the $60 \mathrm{kDa}$ hsp, respectively.

Among the different chlamydial components, the $60 \mathrm{kDahsp}$ has been identified as potentially a major factor involved in the pathology secondary to an infection. This protein has been found to have approximately $50 \%$ amino acid sequence similarity to the human $60 \mathrm{kDa}$ hsp (Morrison et al., 1990). Thus, it has been proposed that an infection with $C$. trachomatis may trigger an autoimmune response to this protein that may then 
lead to an alteration of the structure and function of the affected tissue (Watkins et al., 1986; Morrison et al., 1990). Some experimental evidence for this model was provided by Taylor et al. $(1987,1990)$ and Morrison et al. $(1989 a, b)$ using the ocular model of chlamydial infection. In this system, guinea-pigs and monkeys repeatedly injected with a Triton $X-100$ extract of the chlamydial membrane, containing the $60 \mathrm{kDa}$ hsp, showed pathological changes similar to those observed in trachoma.

(a)

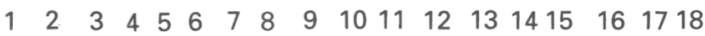

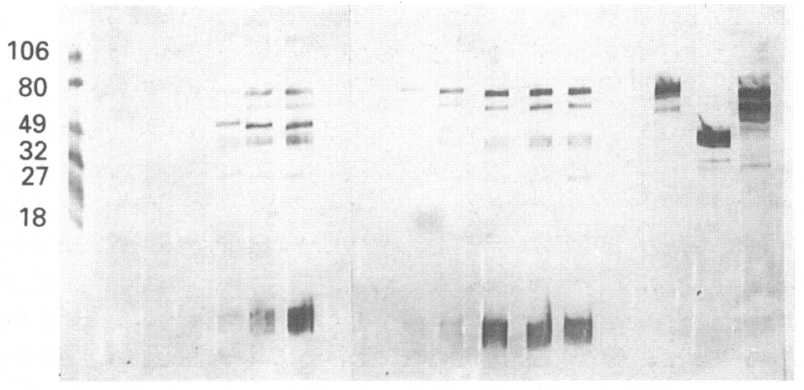

(b)

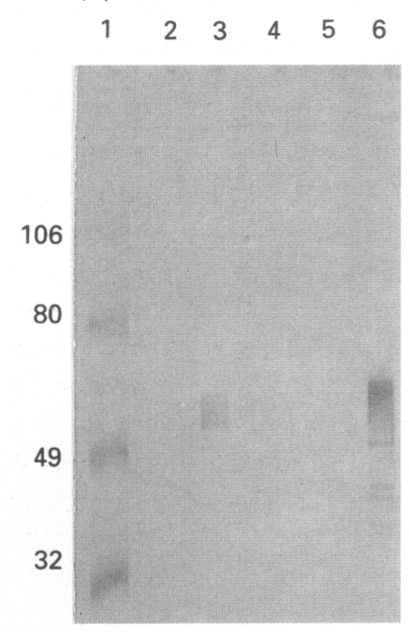

(c)

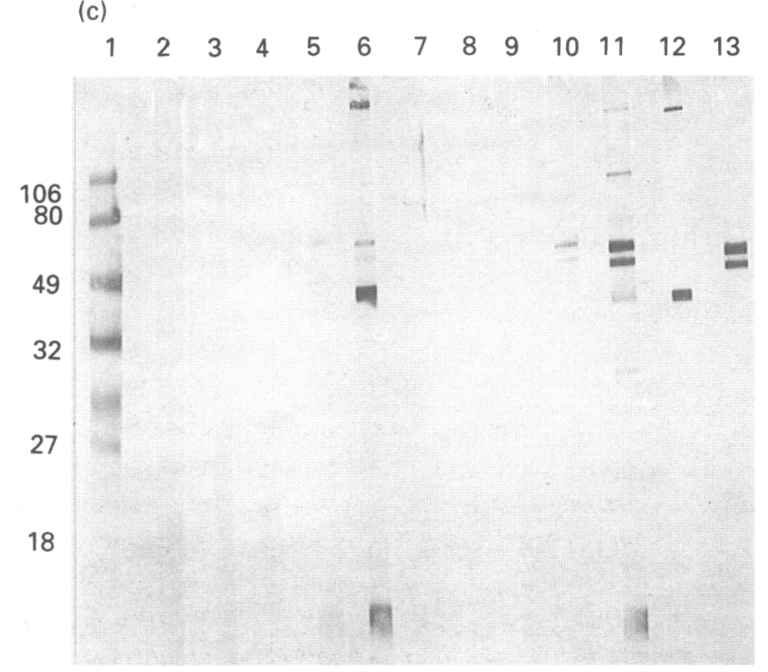

The $60 \mathrm{kDa}$ hsp of mice has also been found to be similar to that of bacteria and other eukaryotes and thus the possibility of an autoimmune mechanism could be analysed in the mouse model (Gupta, 1990). Some investigators have looked at genetic factors in the host that might be linked to susceptibility to sequelae resulting from a chlamydial infection and thus, to reactivity to the $60 \mathrm{kDa}$ hsp. For example, Tuffrey et al. (1992) tested several inbred strains of mice and observed that the $\mathrm{C} 3 \mathrm{H}$ $\left(\mathrm{H}-2^{\circ}\right)$ and $\mathrm{C} 3 \mathrm{H} / \mathrm{He}-\mathrm{mg}\left(\mathrm{H}-2^{k}\right)$ mice infected once in the upper genital tract with the $C$. trachomatis $\mathrm{E}$ serovar had a lower fertility rate than that of the control mice. In contrast, the $B A L B / c$ or congenic $B A L B / K$ mice, which also have the $\mathrm{H}-2^{\mathrm{k}}$ haplotype, did not have lower fertility. On the basis of these observations, they concluded that, although susceptibility to chlamydial salpingitis and infertility were under genetic control, this was not solely associated with the major $\mathrm{H}-2$ complex. Zhong and Brunham (1992) analysed antibody responses to the chlamydial 60 and $70 \mathrm{kDa}$ hsps following i.p. and i.v. injection with elementary bodies of the $C$. trachomatis serovars $B$ and $C$ into 17 different strains of mice. They concluded that, of the six $\mathrm{H}-2$ haplotypes tested, only mice with the $\mathrm{H}-2^{\mathrm{b}}$ haplotype had low antibody responses to the $60 \mathrm{kDa}$ hsp, while $\mathrm{H}-2^{\mathrm{d}}$ mice had a high antibody response to the $70 \mathrm{kDa}$ hsp. By using congenic and $\mathrm{H}-2$ recombinant strains, they mapped the responses to the 60 and $70 \mathrm{kDa}$ hsp to the $\mathrm{K}-\mathrm{I} A$ region of the $\mathrm{H}-2$ locus.

Thus, on the basis of the results obtained by Zhong and Brunham (1992) we tested two inbred strains of mice that had been found to have a high and a low antibody response, as measured by ELISA, to the $60 \mathrm{kDa}$ hsp. We detected by western blot an antibody response to the $60 \mathrm{kDa}$ hsp in the $\mathrm{C} 3 \mathrm{H}$ mice but not in the $\mathrm{C} 57 \mathrm{BL} / 6$ mice. The fact that we did not observe antibodies to the $60 \mathrm{kDa}$ hsp in the C57BL/6 mice may be due to several factors. The western blot may be less sensitive than ELISA, or the immunization protocol used by Zhong and Brunham (1992) could be more efficient at eliciting

Fig. 5. (a) Western blot analyses of the IgG response in the serum of $\mathrm{C} 3 \mathrm{H}$ and $\mathrm{C} 57 \mathrm{BL} / 6$ mice to Chlamydia trachomatis mouse pneumonitis biovar elementary bodies. Lane 1 : molecular weight markers. Lanes 2-7, serum samples of $\mathrm{C} 3 \mathrm{H}$ mice corresponding to days $0,7,12$, 18,25 and 33 after inoculation, respectively. Lane 8: serum sample from mock-infected $\mathrm{C} 3 \mathrm{H}$ mice at 25 days after inoculation. Lanes 9-14, serum samples of C57BL/6 mice corresponding to days $0,7,12$, 18, 25 and 33 after inoculation. Lane 15: serum sample from mock-infected C57BL/6 mice at 25 days after inoculation. Lane 16: anti-60-kDa hsp mAb. Lane 17: anti-major outer membrane protein $\mathrm{mAb}$. Lane 18: anti-60-kDa cysteine-rich protein $\mathrm{mAb}$. (b) Western blot analysis of the $\operatorname{lgG}$ response in serum of $\mathrm{C} 3 \mathrm{H}$ and $\mathrm{C} 57 \mathrm{BL} / 6$ mice to the recombinant $C$. trachomatis serovar $A 60 \mathrm{kDa}$ hsp. Lane 1 : molecular weight markers. Lanes 2 and 3 correspond to days 0 and 42 after inoculation of the $\mathrm{C} 3 \mathrm{H}$ mice, respectively. Lanes 4 and 5 represent days 0 and 42 after infection of the C57BL/6 mice, respectively. Lane 6: monoclonal antibody to the $C$. trachomatis $60 \mathrm{kDa}$ hsp. (c) Western blot analyses of the total Ig response in the vaginal secretions of $\mathrm{C} 3 \mathrm{H}$ and $\mathrm{C} 57 \mathrm{BL} / 6$ mice. Molecular weight markers are on Lane 1 . Lanes 2-6 correspond to days $0,8,15,22$ and 35 after inoculation of the $\mathrm{C} 3 \mathrm{H}$ mice, respectively. Lanes 7-11 represent days $0,8,15,22$ and 35 after inoculation of $\mathrm{C} 57 \mathrm{BL} / 6$ mice, respectively. Lane 12 : anti-60-kDa cysteine-rich protein $\mathrm{mAb}$. Lane 13: anti-major outer membrane protein $\mathrm{mAb}$. 
Table 1. Results of fertility studies in two strains of mice

\begin{tabular}{|c|c|c|c|c|c|c|c|c|}
\hline \multirow[b]{3}{*}{ Mouse strain } & \multirow{2}{*}{\multicolumn{2}{|c|}{ Bilaterally pregnant mice/total number of mice (\%) }} & \multicolumn{6}{|c|}{ Average number of embryos/mouse } \\
\hline & & & \multicolumn{2}{|c|}{ Total } & \multicolumn{2}{|c|}{ Right horn } & \multicolumn{2}{|c|}{ Left horn } \\
\hline & Infected & Control & Infected & Control & Infected & Control & Infected & Control \\
\hline $\mathrm{C} 3 \mathrm{H}$ & $1 / 12 \quad(8)^{*}$ & $8 / 11(73)$ & $2.7^{*}$ & 8.7 & $2^{*}$ & 5.1 & $0.7^{*}$ & 3.5 \\
\hline C57BL/6 & $3 / 12(25)^{*}$ & $9 / 11(82)$ & $3.8^{*}$ & 7.7 & 3.6 & 3.8 & $0.25^{*}$ & 3.8 \\
\hline
\end{tabular}

*Significantly different $(P<0.05)$ from control value.

a response to the $60 \mathrm{kDa}$ than was our intrabursal injection. However, in our experimental model the fertility of both strains of mice was significantly decreased after a single intrabursal inoculation, although in the $\mathrm{C} 3 \mathrm{H}$ mice fertility was more affected than it was in the C57BL/6 mice. For example, $\mathrm{C} 3 \mathrm{H}$ mice showed a greater decrease in the number of pregnant mice and fewer embryos per mouse than did the C57BL/6 strain. In addition, infertility occurred not only in the infected uterine horn but also in the other horn of the $\mathrm{C} 3 \mathrm{H}$ mice. However, the fact that high infertility rates were obtained after a single infection suggests that, at least in this animal model, it is unlikely that an autoimmune phenomenon can account for the main pathogenesis of the sequelae. Even the infertility occurring in the other uterine horn is probably the result of the intracanalicular spreading of the infection from the left to the right uterine horn and not due to immunological damage. In support of this mechanism, we have recently observed that when $B A L B / c\left(H-2^{d}\right)$ mice were inoculated with different doses of $C$. trachomatis MoPn in the left uterine horn, animals that received a high inoculum $\left(1 \times 10^{6}\right.$ or $1 \times 10^{7} \mathrm{IFUs}$ per mouse) became bilaterally infertile, while those receiving a lower inoculum ( $1 \times 10^{5}$ or $1 \times 10^{4}$ IFUs per mouse) became infertile only in the left side ( $\mathrm{Pal}$ et al., unpublished data). In $\mathrm{C} 3 \mathrm{H}$ mice, there was an immune reaction to the infection that was not only qualitatively different from that of the C57BL/6 mice, as shown by the reactivities to the $50 \mathrm{kDa}$ and the $60 \mathrm{kDa}$ hsp, but was also quantitatively weaker and delayed. As a result, the infection was more severe and this may account for the greater decrease in fertility.

Swiss Webster white mice developed salpingitis followed by infertility after a single inoculation with the $C$. trachomatis MoPn biovar (Swenson et al., 1983; Swenson and Schachter, 1984). In this model a significant immune response is mounted against the $60 \mathrm{kDa}$ hsp ( $\mathrm{Pal}$ et al., 1993). There is also evidence indicating that in $B A L B / c\left(H-2^{d}\right)$ mice, which have a low immune response to the $60 \mathrm{kDa}$ hsp, a single injection with the C. trachomatis MoPn biovar into the ovarian bursa results in infertility (S. Pal, T. J. Fielder, E. M. Paterson and L. M. de la Maza, unpublished data). Thus, at least with the $C$. trachomatis MoPn, a single inoculation into the upper genital tract can induce infertility in three inbred and one outbred strain of mice. There are several reasons why Tuffrey et al. (1992) did not obtain infertility in the BALB/c mice. In their experiments they infected mice with the human $C$. trachomatis $E$ serovar and since mice are not the natural host for this chlamydial strain they may be more resistant to infection. In addition, the dose used and the administration of progesterone may affect the sequelae of the disease.
In conclusion, the fact that in the mouse model tubal damage occurs after a single infection, and is independent of the reactivity to the $60 \mathrm{kDa}$ hsp does not in principle support an autoimmune mechanism for the sequelae. The abnormalities in the oviduct may be the direct result of the chlamydial infection that leads to structural and functional damage of the mucosal layer or the supporting tissues. In the mouse model, however, repeated infections have been associated with more severe disease (Tuffrey et al., 1990). This is probably similar in humans, where in certain individuals a single acute episode may lead to long-term sequelae, while in others multiple infections may be required to produce permanent damage. The infecting dose, time of the menstrual cycle, strain of $C$. trachomatis, in addition to the genetic background of the individual, may play a critical role in the outcome of the infection. The assumption that the pathogenesis resulting from a chlamydial infection is exclusively the result of an autoimmune reaction to the $60 \mathrm{kDa}$ hsp is premature. Reactivity to the $60 \mathrm{kDa}$ hsp is an expression of a nonspecific immune response to stress that has been reported in patients with disorders ranging from tuberculosis to schizophrenia (Shinnick, 1991; Kilidireas et al., 1992). In addition, the genital tract is a privileged immunological site that is continuously subject to immunological insults, including the menstrual cycle, the influence of paternal antigens during pregnancy and frequent exposure to spermatozoa and microorganisms. Thus, C. trachomatis would have to be able to elicit a unique host response in the genital tract to evoke an autoimmune mechanism.

This work was supported by Public Health Service grants (AI-32248 and AI-30499) from the National Institute of Allergy and Infectious Diseases.

\section{References}

Barron AL, White HJ, Rank RG, Soloff BL and Moses EB (1981) A new animal model for the study of Chlamydia trachomatis genital infection: infection of mice with the agent of mouse pneumonitis joumal of Infectious Diseases 143 63-66

Brunham RC, Peeling R, Maclean I, Kosseim ML and Paraskevas M (1992) Chlamydia trachomatis-associated ectopic pregnancy: serologic and histologic correlates Journal of Infectious Diseases 165 1076-1081

Caldwell HD, Kromhout J and Schachter J (1981) Purification and characterization of outer membrane protein of Chlamydia trachomatis Infection and Immunity 31 1161-1176

Coles AM, Crosby AH and Pearce JH (1991) Analysis of the human serological response to Chlamydia trachomatis $60-\mathrm{kDa}$ proteins by two dimensional electrophoresis and immunoblotting FEMS Microbiological Letters 81 299-304 
Fielder TJ, Pal S, Peterson EM and de la Maza LM (1991) Sequence of the gene encoding the major outer membrane protein of the mouse pneumonitis biovar of Chlamydia trachomatis Gene 106 137-138

Fitch WM, Peterson EM and de la Maza LM (1993) Phylogenetic analysis of the outer membrane protein genes of Chlamydiae and its implications for vaccine development Molecular Biology and Evolution $10892-913$

Grayston JT and Wang SP (1978) The potential for vaccine against infection of the genital tract with Chlamydia trachomatis Sexually Transmitted Diseases 5 73-77

Gump DW, Gibson M and Ashiaga T (1983) Evidence of prior pelvic inflammatory disease and its relationship to Chlamydia trachomatis antibody and intrauterine contraceptive device use in infertile women American Joumal of Obstetrics and Gynecology 146 153-159

Gupta RS (1990) Sequence and structural homology between a mouse T-complex protein TCP-I and the "chaperonin" family of bacterial (GroEL, $60-65 \mathrm{kDa}$ heat shock antigen) and eukaryotic proteins Biochemistry International 20 833-841

Kilidireas K, Latov N, Strauss DH, Gorig AD, Hashim GA, Gorman JM and Sadiq SA (1992) Antibodies to the human $60 \mathrm{kDa}$ heat-shock protein in patients with schizophrenia Lancet 340 569-572

Mardh PA (1985) Chlamydial infection. A multidisciplinary concern. In Medical Virology IV, pp 325-347 Ed. LM de la Maza and EM Peterson. Lawrence Earlbaum Associates, Hillsdale

Morrison RP, Belland RJ, Lyng K and Caldwell HD (1989a) Chlamydial disease pathogenesis: the $57-\mathrm{kD}$ chlamydial hypersensitivity antigen is a stress response protein Journal of Experimental Medicine 170 1271-1283

Morrison RP, Lyng K and Caldwell HD (1989b) Chlamydial disease pathogenesis: ocular hypersensitivity elicited by a genus-specific $57-\mathrm{kD}$ protein Journal of Experimental Medicine $169663-675$

Morrison RP, Su H, Lyng K and Yuan Y (1990) The Chlamydia trachomatis hyp operon is homologous to the groE stress response operon of Escherichia coli Infection and Immunity $\mathbf{5 8}$ 2701-2705

Nigg C (1942) An unidentified virus which produces pneumonia and systemic infection in mice Science 99 49-50

Nigg C and Eaton MD (1944) Isolation from normal mice of a pneumotropic virus which forms elementary bodies Journal of Experimental Medicine 79 497-509

Pal S, Fielder TJ, Peterson EM and de la Maza LM (1993) Analysis of the immune response in mice following intrauterine infection with the Chlamydia trachomatis mouse pneumonitis biovar Infection and Immunity 61 772-776

Patton DL, Halbert SA, Kuo CC, Wang SP and Holmes KK (1983) Host response to primary infection of the fallopian tube in pig tailed monkeys Fertility and Sterility 40 829-840

Peterson EM, Zhong G, Carlson E and de la Maza LM (1988) Protective role of magnesium in the neutralization by antibodies of Chlamydia trachomatis infectivity Infection and Immunity 56 885-891

Peterson EM, Oda R, Tse P, Gastaldi C, Stone SC and de la Maza LM (1989) Comparison of a single-antigen micro-immunofluorescence assay and inclusion fluorescent antibody assay for detecting chlamydial antibodies and correlation of the results with neutralizing ability Journal of Clinical Microbiology 27 350-352
Schachter J (1983) Epidemiology of Chlamydia trachomatis infections. In Medical Virology II, pp 111-120 Ed. LM de la Maza and EM Peterson. Elsevier Biomedical, New York

Schagger $\mathbf{H}$ and von Jagow G (1987) Tricine-sodium dodecyl sulphate polyacrylamide gel electrophoresis for the separation of proteins in the range from 1 to $100 \mathrm{kDa}$ Analytical Biochemistry $166368-379$

Shinnick TM (1991) Heat shock proteins as antigens of bacterial and parasitic pathogens Current Topics in Microbiology and Immunology 167 145-160

Swenson CE and Schachter J (1984) Infertility as a consequence of chlamydial infection of the upper genital tract in female mice Sexually Transmitted Diseases 11 64-67

Swenson CE, Donegan E and Schachter J (1983) Chlamydia trachomatis-induced salpingitis in mice Journal of Infectious Diseases 148 1101-1107

Taylor HR, Johnson SL, Schachter J, Caldwell HD and Prendergast RA (1987) Pathogenesis of trachoma: the stimulus for inflammation Joumal of Immunology 138 3023-3027

Taylor HR, Maclean IW, Brunham RC, Pal S and Whittum-Hudson JA (1990) Chlamydial heat shock proteins and trachoma Infection and Immunity 58 3061-3063

Tuffrey M, Falder P, Gale J, Quinn T and Taylor-Robinson D (1986) Infertility in mice infected genitally with a human strain of Chlamydia trachomatis Journal of Reproduction and Fertility $\mathbf{7 8} 251-260$

Tuffrey M, Alexander GG and Taylor-Robinson D (1990) Severity of salpingitis in mice after primary and repeated inoculation with a human strain of Chlamydia trachomatis British Joumal of Experimental Pathology 71 403-410

Tuffrey M, Alexander F, Woods C and Taylor-Robinson D (1992) Genetic susceptibility to chlamydial salpingitis and subsequent infertility in mice. Journal of Reproduction and Fertility 95 31-38

Wagar EA, Schachter J, Bavoil P and Stephens RS (1990) Differential human serological response to two 60,000 molecular weight Chlamydia trachomatis antigens Journal of Infectious Diseases 162 922-927

Ward ME (1992) Chlamydial vaccines-future trends Journal of Infection 25 Supplement I 11-26

Watkins NG, Hadlow WJ, Moss AB and Caldwell HD (1986) Ocular delayed hypersensitivity: a pathogenetic mechanism of chlamydial conjunctivitis in guinea pigs Proceedings of the National Academy of Sciences, USA 83 7480-7484

Westrom L (1975) Effect of acute pelvic inflammatory disease on fertility American Journal of Obstetrics and Gynecology 121 707-713

Westrom L (1980) Incidence, prevalence, and trends of acute pelvic inflammatory disease and its consequences in industrialized countries American Journal of Obstetrics and Gynecology 138 880-892

Westrom L (1989) Pelvic inflammatory disease and other sexually transmitted diseases Current Opinion in Obstetrics and Gynecology 1 5-10

Westrom L and Mardh PA (1983) Chlamydial salpingitis British Medical Bulletin 39 145-150

Zhong G and Brunham RC (1992) Antibody responses to the chlamydial heat shock proteins hsp60 and hsp70 are H-2 linked Infection and Immunity 60 3143-3149 